\title{
POPULAR GENRES: SCIENCE FICTION AND FANTASY, DETECTIVE NOVEL, THRILLER ${ }^{1}$
}

\section{Science Fiction}

In Romania, the Science Fiction genre is marked by the realist socialist aesthetic of the 1950s. Prior to 1948, most of the local attempts at exploring this genre had been pretty inconsistent. Alongside several pioneering works of the $19^{\text {th }}$ century, only Victor Anestin's În anul 4000 sau O călătorie la Venus [In the Year 4000. A Journey to Venus] (1899), Un Român în lună [A Romanian on the Moon] (1914), by Henri Stahl, or Orașele scufundate [The Sunken Cities] (1937) by F. Aderca, are worth mentioning. These are rather isolated works that fail to lay the foundations for a Romanian rendition of the genre. The socialist regime, as well as its Marxist underpinning, were inspired by a secular and scientific worldview, focusing their attention on the exact sciences, e.g., physics, astronomy, chemistry, and biology, precisely those usually lying at the core of Science Fiction literature. Having been introduced deliberately and enjoying institutional lobby, being hosted by a dedicated and highly popular publication during that time, "Colecția 'Povestiri științifico-fantastice"” (CPSF) ["The 'Science Fiction Stories' Collection"], Science Fiction literature was one of the most efficient channels through which scientific content and ideology was disseminated during the 1950s.

Writers such as I.M. Ștefan (1922-1992) and Radu Nor (1921-2006), who were behind the first Science Fiction novel in communist Romania, Drum printre aștri [Journey among the Stars] (1954), an adventure novel built on realist socialist conventions, were among the most prominent authors of that time. Drum printre aștri draws on Soviet inspiration to become an illustration of space opera: the novel depicts the adventures of two curious astronauts with an ambition to chart the galaxy. A Romanian team is boarded on an asteroid, which it intersects with help from a custom designed and engineered Romanian rocket; on the asteroid, the team circumnavigates the solar system for the duration of one year, gathering information and facing various threats. Encyclopaedic information is constantly substantiated by scientific sources (Soviet scientists being the main reference in this regard), but also by the period's futuristic projections: the planet of Venus hosts boiling hot geysers, luxurious vegetation, and freakishly large animals (an

\footnotetext{
${ }^{1}$ Preliminary versions of this article were published under the titles "Literatura polițistă" ["Detective Literature"] and "Literatura SF" ["Science Fiction Literature"] in Eugen Simion (ed.), Dicționarul general al literaturii române [General Dictionary of Romanian Literature], second edition, vol. IV (H-L), București, Muzeul Literaturii Române, 2017, pp. 777-781, 781-786.
} 
aggressive lizard standing 15 meters tall is promptly rendered harmless with a "ray gun").

The 1960s led to the genre's relative emancipation from ideological demands, in the sense of replacing explicit propaganda with a less frigid "humanism", through authors who had "escaped" the 1950s, albeit not without making compromises: Vladimir Colin, Adrian Rogoz (important figure in the genre, but also a reputable writer in his own right nonetheless), Sergiu Fărcășan, or Camil Baciu. Belonging to the same generation, but proving his abilities as a Science Fiction writer only later in life and quite surprisingly for his contemporaries, Ov. S. Crohmălniceanu will author what will become two future landmarks of the genre and probably the most skilfully devised speculative works prior to 1990: Istorii insolite [Extraordinary Stories] (1980) and Alte istorii insolite [Other Extraordinary Stories] (1986).

During the 1970s, the genre takes a blow, as the CPSF collection is discontinued, but it will still enjoy support especially through the Albatros Publishing House, dedicated to a young audience, and particularly through the Fantastic Club collection (which hosts translated classics such as H. G. Wells, Edgar Rice Burroughs, Ray Bradbury, Gérard Klein, Stanisław Lem, among others, as well as contemporary Romanian authors - from Horia Aramă and Vladimir Colin to Mihail Grămescu and Alexandru Ungureanu). However, a coherent generation takes shape through contributions by Gheorghe Săsărman, the author of the Borgesian novel Cuadratura cercului. Fals tratat de urbogonie [The Circle's Quadrature. False Treaty in Urbogony] (1975), by those of Horia Aramă, Mircea Opriță, but also by the Science Fiction duo consisting of George Anania (19412013) and Romulus Bărbulescu (1925-2010).

The truly professional period of the genre unfolds during the 1980s, when a socalled New Wave emerges on the Romanian Science Fiction scene, anticipated by Mihail Grămescu (1951-2014), whose debut novel, Aporisticon, is published in 1981, and by other names such as Cristian Tudor Popescu, Alexandru Ungureanu, Rodica Bretin, Ovidiu Bufnilă, and Silviu Genescu. Several of them will make their debut only after the 1989 regime change. The 1980s constituted a hotbed for the formation of strongly knit local fanbases and communities of writers as well, publishing numerous fanzines and participating in literary debates, discreetly passing around photocopies of Western works or illicit translations made by legendary literary translators within the fandom - such as Ion Doru Brana or Mihai-Dan Pavelescu - of works by Frank Herbert of William Gibson. 1982 sees the publication of the Alamanahul Anticipatia [Anticipation Literary Almanac], reuniting Romanian and translated authors alike and having an initial print run of 100.000 copies. Many of the authors active during the 1980s possessed a background in science and had degrees in engineering; they were clearly more knowledgeable in technical fields as their dilettante predecessors and could more easily approach the more sophisticated concepts pertaining to "Hard Science Fiction". 
After the regime change, a series of complementary processes begin to take place. On the one hand, there is a clear boom in the number of translated Science Fiction titles, the most consistent of which owes to the "Nautilus" collection, hosted by Nemira Publishing House. On the other hand, Romanian Science Fiction literature undergoes a fatal retrenchment and is eventually declared dead; as Cristian Tudor Popescu claimed, Romanian Science Fiction

...possessed consistence inasmuch as it could be a way in which young people, and not only them, could circumvent and evade the political situation prior to 1989. It was typical of an era. That era is now gone. When he met his demise, Ceaușescu took along with him, among many other things, the Romanian Science Fiction as well ${ }^{2}$.

This was, however, an exaggerated claim. Albeit translations were quantitatively more consistent (especially from the Anglo-Saxon classic authors) than the production of local Science Fiction, the genre underwent a visible revival. The commencement of 1990s Science Fiction is marked by the publication of Jurnalul SF [The SF Journal] (where Popescu's claims are also contested), which hosts the emergence of a new tendency in the Romanian sci-fi community, built chiefly on William Gibson's cyberpunk works. The backdrop of these new works is mainly international or postnational, but not exclusively so. Romania is featured as independent country by several authors: Liviu Radu, George Lazăr, Marian Truță, Doru Stoica, Cristian M. Teodorescu, and others.

Another self-deprecating preconception of Romanian Science Fiction is hereby set aside; according to Cristian Tudor Popescu, one of its "deeply rooted and defining contradictions was the impossibility of writing a ground-breaking piece about an astronaut named Vasile - 'the astronaut Vasile' could inspire nothing but ridicule" ${ }^{3}$. This "impossibility" had been manifest chiefly during the 1980s, finding expression in a joke about "the Slobozia Spaceport", circulated among Science Fiction fans during the 1980s - a reaction to the discontinuation of Romania's modernization projects as a result of Ceaușescu's austerity measures, but also to the period's cultural protochronist backwardness and kitsch nationalism - and referring, in Marxist terms, to the considerable difference between the country's core and its superstructure (between how Romania really presented itself and the manner in which Science Fiction writers were pressured to image it). During the 1950s and 1970s, Romanian authors, like nearly all the pioneers of a certain field, had gone through an idealist phase, wherein they had imaged the future(s) of Romania in ways which seem ridiculously naïve to a contemporary observer.

However, unlike their predecessors, the writers of the 1980s were much more cynical, readily ridiculing scenarios in which "Romania conquers the Cosmos". This helps explain the joke with the "Slobozia Spaceport", which projected Star

\footnotetext{
${ }^{2}$ Cristian Tudor Popescu, "Ceaușescu a luat în mormânt și SF-ul românesc" ["Ceaușescu Took the Romanian Science Fiction Along to the Grave"]. Interview by Viorel Ilișoi, Timpul, 1994, 1 (republished in Jurnalul SF, 1994, 61, p. 15).

${ }^{3}$ Cristian Tudor Popescu, "Literatura zilei" ["Literature of Today"], România literară, 1999, 31, p. 10.
} 
Wars levels of technological progress unto Slobozia, a small town in the middle of the Bărăgan Plain. The most renowned author making use of these farcical references during the 1980s was Ioan Groșan; in his Epopeea spațială 2084 [2084, A Space Odyssey] and in his Planeta Mediocrilor [Planet of the Undistinguished], he mocked most of the clichés prevalent on the socialist Science Fiction scene unsurprisingly, these works could only be published in print after 1989, having been published previously in the Știință și tehnică [Science and Engineering] magazine, under Ioan Albescu's approval (as he was editor for the Almanahul Anticipația).

Throughout the 1990s, however, as Romanian culture distanced itself from the ostentatious nationalism in which it had indulged before and adopted postmodern technological imagery, the national specificity became yet again an acceptable content to employ in Romanian Science Fiction, this time unironically, starting with the edited volume Motocentauri pe acoperișul lumii [Moto-centaurs on the Roof of the World] (1995), which conceives an alternative history in which the Thracian Empire evolved from Burebista's centralized state to Bishop Ring colonies surrounding Earth during the $23^{\text {rd }}$ century. Although the writers active during the 1990s (Sebastian A. Corn, Dănuț Ivănescu, Ona Frantz, Florin Pîtea, Liviu Radu, Michael Haulică, Don Simon, Costi Gurgu, and others) are not entirely uninfluenced by the general aesthetic tendencies of the 1980s (for which textual and stylistic experiments alongside narrative fragmentation were key), they evolve closer to the Western conception of postmodernism through their penchant for Anglo-Saxon popular literature, through a more technologically aware mindset, and through a vaster philosophical outreach than their immediate predecessors, who employed realism in attempting - and also believing that they were successful in their undertaking - to construct a postmodernist discourse in works about commuters which, albeit stylistically valuable, lacked in conceptual consistence.

In fact, Romanian Science Fiction literature between 1990 and 2010 (for which the 1980s laid the foundations) is unique in that does not consolidate a genuine popular culture, although it employs its artefacts. What it clearly lacks is a real market demand, which the loyal fanbase cannot substitute on its own. Romanian Science Fiction is rather a literary avantgarde through which new forms of literary production are assimilated into Romanian culture, starting with the computers and operating systems featured in Cristian Tudor Popescu's works from the 1980s and all the way to the complex cyber-capitalist networks imagined by Sebastian A. Corn in his Adrenergic! during the 1990s; in fact, the genre had possessed a pioneering role in the dissemination of technological trivia - albeit in a dominantly primitive literary form - since the 1950s and 1960s, which abounded in texts featuring spaceships and robots. The cultural importance of this literary production was implicitly acknowledged by Mircea Cărtărescu in his 2015 Solenoid, a tribute he pays to Science Fiction by making use of its narrative conventions (hi-tech gizmos and devices, global conspiracies with apocalyptic effects, etc.) and 
combining them with metatextual autobiographical elements such as in his Orbitor [Blinding] trilogy.

An American author, Norman Spinrad, when given the chance of writing a postface to a collected edition of Romanian short stories, remarked - politely exaggerating, perhaps - that he can sense "no resemblance to American Science Fiction whatsoever" and that the Romanian texts are unique "at every level, from the surrealist narrative of the stories to the intense magic realism of their imagery"; "what you are about to read", he claimed, "is closer to the spirit of Eugen Ionesco than of that of Heinlein or E.E. Smith"4. Spinrad's observations, besides identifying in surrealism a local particularity, seemed to point towards another fact as well - the dissimilarity of Romanian Science Fiction with prevalent Western formulas. Equating commercial literature with "paraliterary" forms such as Science Fiction is nonetheless a penchant of Western culture and a Western "form", which cannot find solid ground in post-1989 liberalized Romania, however, on account of the country lacking a sufficiently large book market. On the other hand, flying under the radar of mainstream culture and subsequently failing to be assimilated into its ranks, particularly by being ignored by literary criticism, Romanian Science Fiction could not exert a proper influence on the literary avantgarde, although it was later assimilated into the works of an established author such as Mircea Cărtărescu. The case study authored by the Spanish essayist and literary translator Maríano Martín Rodríguez regarding the assimilation of Science Fiction literature in the Romanian literary history books during postcommunism advanced the following conclusions:

The official contempt displayed by the central Romanian literary institutions towards Science Fiction as genre, as seen in the most prominent literary histories, seems not only incomprehensible, but is also detrimental. How can Romanian literary historiography or even the canon be renewed without considering the contributions of the genre, which has demonstrated its viability and universalist potential time and time again, through its narrative production, having enjoyed numerous translations into other languages, as well as through its critical output? Its banishment from the Romanian literary canon is not only untimely, given that we are still living in postmodernity, but also unacceptable under an historical and scientifical point of view, considering its obvious value ${ }^{5}$.

The previous historical overview is an illustration of Fredric Jameson-Franco Moretti "law" regarding the manner in which peripheric cultures fuse together a

\footnotetext{
${ }^{4}$ Norman Spinrad, "Postfață" ["Afterword"], in Antologia science-fiction Nemira '94 [The 1994 Nemira Science Fiction Anthology]. Selected by Romulus Bărbulescu and George Anania. With a foreword by N. Lee Wood, București, Nemira, 1994, pp. 208-209.

${ }^{5}$ Maríano Martín Rodríguez, "Cine dictează canonul? Spirit conservator și inovație în istoriografia literară românească din primul deceniu al secolului al XXI-lea. Cazul literaturii științifico-fantastice" ["Who Dictates the Canon? Conservative Spirit and Innovation in Romanian Literary Historiography during the First Decade of the $21^{\text {st }}$ Century. The Case of Science Fiction Literature"], Viața românească", 2012, 7-8, pp. 135-136.
} 
Western form and a local content ${ }^{6}$. The link between commercial literature and "paraliterature" such as Science Fiction remains a Western "form", which cannot be yet assimilated by Romanian culture in the absence of a sufficiently large book market.

\section{Fantasy}

This bears a striking similarity to the emergence of Romanian fantasy. The genre's Romanian pioneer and accidental forerunner is Vladimir Colin (19211991). Legendele țării lui Vam [Legends of Vamland] (1961), Divertisment pentru vrăjitoare [Entertainment for Witches] (a short novel included in the 1971 book Capcanele timpului [Time Traps]), a combination of sword \& sorcery elements and Gérard Klein's style in Seniorii războiului [The Overlords of War]), or Grifonul lui Ulise [Ulysses' Gryphon] (1976) are just a few of the titles that established Colin as the genre's Romanian founder and the first ever to have made use of local particularities. Another representative author is Iordan Chimet (1924-2006), through his 1970 Inchide ochii și vei vedea Orașul [Close Your Eyes and You Will See the City]. For a long time, however, Romania had lacked a demand for literary fantasy. The 1975 translation of J.R.R. Tolkien's $O$ poveste cu un hobbit [The Hobbit, or There and Back Again] by the Ion Creangă Publishing House (made by Catinca Ralea, who had converted the fantastical Nordic races to Romanian ones, therefore virtually cancelling their specificity), was to no avail. Even during the 1990 s boom in the book market, the "Nautilus" collection registered but few fantasy titles - foremost, several novels by Abraham Merritt.

It is only during the early 2000s, following the success of the Harry Potter adaptations of J.K. Rowling's books and The Lord of the Rings, the film based on J.R.R. Tolkien's books, which had meanwhile been translated into Romanian as well, that the national book market began to focus its attention on this genre, now too popular to be ignored. Radu Ciubotea's 2005 Apărătorii [The Defenders] is a historical novel with fantasy undertones, hailed as "the first Romanian fantasy", spanning more than 1.000 pages, is disinhibited in its choice of narrative content, as it dares to engage Stephen the Great and a group of ninja worriers within the same fictional decorum. Polirom Publishing House unknowingly publishes two landmarks of the genre, simultaneously two masterpieces of postcommunist Romanian literature: Radu Pavel Gheo's Fairia [Fairia - A Land Faraway] (2004) and Răzvan Rădulescu's Teodosie cel Mic [Theodosius the Small] (2006). Fairia represents the ironic - and at times even satirical - fusion of space opera, the popular fairy tale, and the serialized fantasy, possessing, however, a melodramatic

\footnotetext{
${ }^{6}$ Franco Moretti, "Conjectures on World Literature", in Distant Reading, London - New York, Verso, 2013, p. 50: "[I]n cultures that belong to the periphery of the literary system (which means: almost all cultures, inside and outside Europe), the modern novel first arises not as an autonomous development but as a compromise between a Western formal influence (usually French or English) and local materials".
} 
conclusion, and reflecting, much like Michael Ende's Bastian in The Neverending Story, on the role of the Story and the alienation to which one succumbs once it is over. Other two landmarks of the genre are authored by Sebastian A. Corn. In Imperiul marelui Graal [The Empire of the Great Grail] (2004), a heroic fantasy set in a mixed and uncertain timeline, technology is laboriously advanced, and the reality - or, better yet, the realities - constructed by the narrative is complex and paradoxical, an existential slate unto which several technological endeavours from different timelines simultaneously and haphazardly rewrite the text. Vindecătorul [The Healer] (2008) is set during prehistoric times and follows the adventures of Krog, a civilizing hero whose journey around the Earth lasts - by his own reference system - for two years, but actually spans, not unlike the popular fairy tale, over the course of "a youth without youth and a life without death", i.e. over an entire lifespan (children grow up to become warriors during his leave; as he returns, the woman he had been in love with had grown old).

Tritonic Publishing House, through the fiction.ro collection, coordinated by Michael Haulică, attempted to be more proactive in promoting Romanian fantasy writers. It is Tritonic that hosts Costi Gurcu's (b. 1969) Rețetarium [RecipeArium] (2006), a masterpiece of Romanian fantasy. Written in the early 1990s, yet without being able to find a publishing house willing to publish it (a common occurrence during the precarious circumstances of the book market of that time), the novel represents a very original mixture of fantasy and New Weird, complemented by horror undertones, and constructs, by making use of lush descriptions of culinary delights, a cruel, nonhuman, baroque world hosted by an absolutist Leviathan. Culinary art dictates all socio-political links, as well as all the moral hierarchies of this Rabelaisian world with Science Fiction underpinnings.

Liviu Radu would inaugurate a Romanian fantasy series with his 2007 Waldemar and follow through with Blocul câș [The Tilted Block] (2008), O dupăamiază cu bere și zâne [An Afternoon with Beer and Fairies] (2009), and Vânzoleli nocturne [Nocturnal Hassles] (2012) as subsequent instalments. A mixture of heroic and comic fantasy following the style of Roger Zalazny in his Amber series, Wandemar makes use of the specifically Romanian and international mythology of the "iele" - faeries bearing semblance to nymphs, dryads, and naiads - and of the "pricolici" - a mixture of vampires and werewolves in Romanian imaginary -, contriving otherworldly battles, including some that take place against the familiar backdrop of Bucharest. Liviu Radu will eventually author a new series, this time hosted by Nemira Publishing House, containing elements of light fantasy; its first instalment, Armata moliilor [Moth Army] (2012), will be continued through La galop prin piramidă [Galloping through the Pyramid] (2013) and Infruntarea nemuritorilor [The Clash of the Immortals] (2014). This new series is a combination between One Thousand and One Nights and George R.R. Martin's 1986 Tuf Voyaging.

Recently, through the Harap Alb continuă [Harap Alb Continues] comic book series, a sequel of Ion Creangă's well-known story, inspired by Tolkien, Marian 
Coman has attempted to test whether or not a fantasy comic book series could be successful on the Romanian book market. One of the series' spin-offs is Marian Coman's novel Haiganu. Fluviul Șoaptelor [Haiganu. The River of Whispers] (2015), followed by a second instalment, Haiganu. Furia oarbă [Haiganu. Blind Rage] (2017).

Broadly speaking, Romanian fantasy follows the same trajectory as the Science Fiction genre (both being a global form seeking out a local background in order to shine brighter - the difference being that the latter is much more pronouncedly enriched with Romanian cultural particularities), but they face a common impediment: the absence of a sufficiently mature book market that would generate the necessary momentum for the genres to become truly popular.

\section{Detective Novel}

In Romania, crime fiction is an imported form that gradually adapts to an array of local institutions on their path towards modernization. The beginnings of the genre were still under the strong influence of the sensationalist French paraliterature, chiefly Eugène Sue's The Mysteries of Paris (1843). This helps explain why the relatively modest literary output of $19^{\text {th }}$ century Romania enabled the publication of novels bearing titles such as Mistere Bucureștilor [The Mysteries of Bucharest] by G. Baronzi (1862), Misterele din București [The Mysteries from Bucharest] (1862), by Ioan M. Bujoreanu, Condamnata [The Condemned] (1868), by Emanoil Arghiropol, Crima din Calea Moșilor [The Crime from Moșilor Avenue] (1887; the first Romanian attempt at a spy novel), by Teochar Alexi, Otrăvitoarea din Giurgiu [The Poisoning Woman from Giurgiu] (1884), a "crime novel" by Panait Macri, Din memoriile unui procuror [From the Recollections of a Prosecutor] (1888), by N. Rădulescu Niger, as well as Dramele Veneției sau pumnalul răzbunător [The Tragedies in Venice or the Vengeful Dagger] (1889) and Clotilda sau crimele unei femei [Clotilde, or the Murders of a Woman] (1891), by Alexandru I. Alexandrescu.

With the exception of Baronzi and Bujoreanu, the literary quality of these works is mediocre, as they were nothing but shoddy imitations of French works. At blame is not only the absence of a cultural system capable of inspiring decent literary performance, but also that of modern police institutions that could conduct investigations according to a rational, objective, and, most importantly, formalized set of laws. During that time, the police force enjoys a rather bad reputation, famously summarized by I.L. Caragiale in his character Pristanda, the embodiment of corruption and servitude towards the political status quo. On the other hand, French and British crime fiction had emerged precisely as a result of the formation of coherent penal systems. The first French crime fiction novel, $O$ afacere tenebroasă [A Shady Business] (1841), is, in equal measure, the creation of Balzac and that of Vidocq, the ex-criminal who was to become the founder, under 
Napoleon, of Sûreté Nationale [National Security], or that of Fouché, the founder of the Secret Police during the French Consulate.

As regards the manner in which these bourgeois institutions were mirrored in the works, their particular traits determined the traits of each corresponding literature. Luc Boltanski, for instance, in his comparative analysis of French and British detective fiction, illustrated the consequences of the two nations' differences: whereas in France, the task force could don civil attire and therefore use disguise, the English policemen were required to wear the official uniform. Therefore, the French police officers enjoy a good public image in French crime fiction, whereas in England, the Scotland Yard is reduced to the function of mere aide for the private detective Sherlock Holmes ${ }^{7}$. In conclusion, although Romania imports a foreign form (the detective fiction novel in its primitive form as mystery novel), the Romanian penal system still lacks the coherence that would allow it to find itself reflected in literary production.

After this initial pioneering period, crime fiction nonetheless fails to impose itself on the Romanian literary scene in the interwar period as well. It decisively loses in favour of other forms of popular, commercial literature; during this period, it is rather the romanticised biographies and sentimental-sensationalist novels that are popular and in demand, whereas Romanian-language detective novels fall behind, not least on account of the fact that there are numerous publishing houses laboriously translating foreign detective fiction already. However, there are several prominent authors who seem not to hold detective fiction in the same contempt as their contemporaries: Mateiu Caragiale with his novella Remember (1924) and with his unfinished novel Sub pecetea tainei [Obscured by Mysteries], Victor Eftimiu with his Kimonoul instelat [Starry Kimono] (1932), Mihail Sadoveanu with Baltagul [The Axe] (1930) and Ostrovul lupilor [The Island of Wolves] (1941), and Liviu Rebreanu with Amândoi [Both] (1940).

The Golden Era of Romanian crime fiction will be the communist period, during which the state will deliberately cultivate the genre because of obvious reasons: supporting popular literature can vouchsafe an efficient dissemination of ideology. The foreign form is strong, the local background - set within communism's confines - is also robust. Crime fiction proves to serve a useful purpose for the regime: it cultivates positive representations of policemen and of Securitate officers, depicting them as heroes; it encourages denouncement practices and xenophobia, or at least mistrust towards foreign citizens; it rewrites history from the standpoint of the dominant ideology (for example, the way in which Haralamb Zincă presents the events from August $23^{\text {rd }} 1944$ ); it contrives a myth about Romania possessing a decisive superiority in every field, capable of churning out one invention after the other, making it the target of global envy. Well established in the editorial programs of national publishing houses and lacking genuine competition from translated literature (although the western classics of the

${ }^{7}$ See Luc Boltanski, Énigmes et complots, Paris, Gallimard, 2012. 
genre had already been translated during the 1950s: Edgar Allan Poe, Arthur Conan Doyle, Agatha Christie), local crime fiction (jokingly dubbed "the milițier", from the French denomination of "policier", a play derived from the word used for the police force during communism, "Miliția") enjoys considerable print runs. Several specialised collections activate simultaneously and sometimes promote translated titles as well: the "Cutezătorii" collection at the Tineretului Publishing House, the "Aventura" collection at Albatros Publishing House, "Scorpionul" at Dacia Publishing House, "Sfinx" at the Military Publishing House, "Fantomas" at the Junimea Publishing House, or the "Delfin" collection at the Meridiane Publishing House. As regards the supply of foreign titles in translation, there was only one collection publishing international crime fiction during this time, the "Enigma" collection at Univers Publishing House; many of the titles, however, are from the USSR, Eastern Germany, Czechoslovakia, or Poland. The original crime fiction subgenre of communist Romania (but not only from Romania, but also from China $^{8}$, the USSR, Bulgaria ${ }^{9}$, and the entire Eastern Bloc) consists of the depiction of battles conducted by communist intelligence agencies against hostile agents pursuing to overturn communism and rehabilitate the former regime.

These villains belong to two distinct groups: they can either be remnants of the former system (landowners sabotaging collectivization, members of the Iron Guard who have fled to the mountains to become resistance fighters, former industrialists, or aristocrats) or originate outside of it (chiefly Germans who had previously fought for the Nazis and became capitalist spies in the aftermath of the war, but one can also encounter British or American spies as well). The perpetuators of the former regime are invariably treated with suspicion, regardless of whether or not they had previously been landowners or industrialists. For the odds to turn against a character in a Romanian crime fiction novel, it suffices that he lives in a large, old house or belongs to a so-called distinguished family. The genre was thus conceived as to focus the attention and suspicion of its readerships towards the potentially dangerous elements of society.

Another, more benign category of villains starting to emerge in Romanian crime fiction novels after the first two communist decades is that of the small businessmen, whose existence the regime had allowed in the latter half of the 1960s, and who have been collectively coined "mandatari". In numerous novels, small restaurant owners, as well as those running guest houses are cast as antagonists. By much the same token, professions with a varying degree of regularization, such as actors or singers, are often assigned roles as villains. The heroes are selected, on the one hand, from the ranks of Security or police officers

\footnotetext{
${ }^{8}$ Wei Yan, "Sherlock Holmes Came to China: Detective Fiction, Cultural Meditations, and Chinese Modernity", in Louise Nilsson, David Damrosch, Theo D'Haen (eds.), Crime Fiction as World Literature, New York, Bloomsbury Academic, 2017, p. 254

9 Mihaela P. Harper, “'In Agatha Christies Footsteps': The Cursed Goblet and Contemporary Bulgarian Crime Fiction", in Louise Nilsson, David Damrosch, Theo D'Haen (eds.), Crime Fiction as World Literature, p. 176.
} 
(from the judicial or economic department, but also from the traffic police department). Gradually, as the public image of the Security officer worsens and he becomes a real-life villain, some of the authors will face the difficulty of casting such characters, who cannot be depicted as anything but heroic. For instance: Mircea Vigu, the hero of Nicolae Mărgeanu's novels, is featured as a Securitate officer in A treia noapte fără lună [The Third Moonless Night] (1955) and The Bătălia nevăzută [Unseen Battle] (1958), the first two books in which he features, where he initially confronts the illegal mountain resistance and then an evil network manoeuvred by Western powers seeking to obtain the plans to radioactive ore deposits; throughout the following novels in the series, however, the hero changes his identity and becomes a more neutral officer of the Judicial Police.

There are also alternatives for the role of the detective. Consequently, George Arion will cast a journalist as hero, whereas Vlad Muşatescu casts a writer. Other emblematic heroes are oftentimes teachers and professors: either researchers in STEM fields (chemistry, physics) making revolutionary discoveries which immediately find an application in industrial plants and factories in order to conserve communism's technological upper hand; archaeology professors, conducting field research in the Romanian mountains and discovering all sorts of Dacian treasures representing "Our gift and the gift of our forefathers for the Dacians who will come to see the light of day beyond the walls of warrior fortresses" ${ }^{\prime 10}$. These two basic types of teachers ${ }^{11}$ are illustrative of the regime's objections and wishful projections: shaping a technocratic elite capable of ensuring the regime's self-sufficiency by putting an end to technological imports from the West and which actively participates in the effort of preserving the dominant communist ideology. Of course, all these professors bear rather an ambiguous role, as they can always prove to be deceitful traitors. For instance, in Nicolae Mărgeanu's 1979 Reversul Medaliei [Flipping the Coin], we encounter Mihnea Gelep, one of Romania's top cyberneticians, but also the offspring of an old boyar family - which allows for staging another ideological conflict, the class struggle; the antihero sells Romanian technological secrets abroad, then falls from grace by fleeing to Italy and to the United States, and eventually becomes member of a criminal occult with international ramifications. Understandably, the Secret Police is crucial in its role of safeguarding all these precious secrets and for averting these catastrophes. Precisely because of its role as protector, the Secret Police is very well integrated into communist detective fiction; reading these novels (published at the height of the communist regime, nota bene), one can become aware of how the

\footnotetext{
${ }^{10}$ Gabriel Iuga, Comoara regilor daci [The Treasure Trove of Dacian Kings], București, Editura Tineretului, 1969.

11 The most common triad consists of an old professor, his daughter, and the professor's young apprentice/assistant teacher. Speaking of women's emancipation, the daughter is usually cast either as romantic interest or as domestic aide: she helps her father in his academic work and/or falls in love with his assistant. The daughter's role is to illustrate the transfer of the humanist-communist legacy (abstract as any other intellectual capital) from the older to the younger generation.
} 
officers violate private correspondence or disguise themselves (both these illicit actions pursue the greater good), claiming, for instance, to be engineers when traveling abroad, and so on. Other representative authors are Rodica OjogBrașoveanu, Theodor Constantin, Horia Tecuceanu, Chiril Tricolici, and others.

As opposed to Science Fiction, which had been considerably more solid as a genre between 1948 and 1989 and had survived the regime change, the detective novel underwent a complete and utter dissolution after 1989. This owes not only to the massive wave of translations crushing any attempt made by Romanian authors to keep the genre alive, but also to the fact that, whereas Science Fiction was bound to a background that could eschew any socio-ideological determinations, detective fiction was much too reliant on its characters, the police and State Security officers - some of the regime's most hated agents.

Among the few authors who made the object of postcommunist reprints are preponderantly those whose detectives were journalists (such as George Arion) or whose heroes were, in fact, antiheroes (Rodica Ojog-Brașoveanu); even these two, however, reedited their works themselves in order to survive. There are, indeed, several exceptions, starting with Pavel Coruț, a former intelligence officer. He makes his debut with the 1992 novel Quinta spartă [Broken Quintet] (1992), the first instalment of a series consisting of more than 100 volumes and a work that, according to its author, sold "more than 310.000 copies" alone. His novels combine the prevalent tropes of spy literature with the idiosyncrasies of Science Fiction, culminating in a series of outlandish conspiracy theories involving a fictional Romanian intelligence agency dubbed "The Octagon". Another prominent author is Eugen Ovidiu Chirovici, whose books stage the impression of being, in fact, translations of Western works. These clones of Western paraliterary works illustrate not only Chirovici's versatility as writer, but also an attempt of the Romanian literary field to overcome the unreasonably large influence of translations from Anglo-Saxon sources, as well as the regrettable position of a literary field so narrow so as not to allow for the existence of "commercial literature" as marketable alternative to high-brow literary production, so that the former eventually becomes a mere succession of metaliterary experiments. In fact, following the popularity of postmodern theory during the 1980 s, detective literature, alongside the entirety of commercial literature, undergoes a rehabilitation within mainstream literature and metaliterature, finding itself ranked high in the new hierarchy of literary genres attempting to bridge the ancient gap between low-brow and high-brow culture.

During communism, beyond the relatively moderate interest literary critics such as Mircea Iorgulescu, Voicu Bugariu, or Dan Culcer displayed towards the genre, certain elements of crime fiction have imbued "serious" literature as well, in novels such as Nicolae Breban's Animale bolnave [Sick Animals] or Marin Preda's Cel mai iubit dintre pământeni [The Most Beloved of Earthlings], but also in poetry: Mircea Ivănescu's 1973 poetry collection presents itself as a detective novel. Starting with the 1960s, the "false "policier" emerges under the influence of 
the Nouveau Roman in making use of police investigative methods - for instance, Alain Robbe-Grillet in his 1953 The Erasers or his 1959 In the Labyrinth - as pretext for narrative experiments and formal renewals. This sort of narrative tendencies become customary for the prose writers of the 1980s and for those following in their footsteps (Mircea Cărtărescu, Ion Manolescu, Caius Dobrescu, and others). Therefore, although Romanian crime fiction ceases to be in demand after 1989, it is granted a place in mainstream literature and literary theory.

However, a relative revival of crime fiction as commercial genre is underway, especially through the efforts of Tritonic Publishing House, led by Bogdan Hrib, himself a reputed author within the genre; the new works signed by Daniel Timariu, Teodora Matei, Lucian Dragoș Bogdan, Petru Berteanu, Lucia Verona, Irina Munteanu, and others try to breathe new life into the genre and imbue it with the Romanian postcommunist social structure.

\section{Thriller}

Addressing the "thriller" separately is, perhaps, debatable, as the label can widen to include both Science Fiction novels and crime fiction, spy novels, erotic novels, and so on. The unique particularity of the genre is its inherent rhythm, its quality as page-turner designed for eager, impatient consumption. Precisely because it does not rely on themes that are recognizable only for a limited fanbase, as it is the case with the detective or Science Fiction novel, but exclusively on its quality as pure entertainment, the thriller is more reliant on a cohesive and wellstructured book market. Up until 1990, this market was supplied by authors of spy novels such as Haralamb Zincă, Horia Tecuceanu, Rodica Ojog-Brașoveanu, Chril Tricolici, alongside others, whose dominance was ensured by the book industry's capacity to render any sort of competition against Western thriller authors harmless by limiting the latter's import via translation. However, the postcommunist period saw an upsurge in the number of translations, which more or less crushed any chance of surviving on the book market for all the aforementioned authors, with the exception of Rodica Ojog-Brașoveanu.

The most prominent thriller author after 1989 is Pavel Coruț (b. 1949). His novels are a combination between the prevalent tropes of the spy novel and Science Fiction, generously garnished with conspiracy theories involving the Romanian Secret Police and its postcommunist renditions (rather those fictionalized under the name of the Octagon, and not the contemporary Romanian Intelligence Service, an institution of which the author thinks rather badly ${ }^{12}$ ). Whereas the first novels of the series seem to cultivate realist conventions (albeit the Romanian superspy Petre Varain, Coruț's hero, yields unreasonable parapsychological powers), in later

12 Corut imagines the Octagon as a Romanian intelligence agency different both from the State Security/ Directorate for Foreign Intelligence and from the Romanian Intelligence Service/ Foreign Intelligence Service. 
instalments, the Octagon will take the form of a mighty combatant in a galactic conflict in which Romania will unsurprisingly embody the forces of good. The shift from a planetary-scale to a galactic-scale conspiration is best illustrated through the expansion in meaning suffered by the term "bubuli", through which Corut designates the forces of evil. In Quinta spartă " "bubuli = scorpions = Zionists", respecting the antisemitic conspiracy theories perpetuated in the ranks of the former Securitate and reinforced by the ever-prevalent paranoia about a presumed global Judaic economic domination. In later instalments, however, the series will go beyond this simple equation, transforming the "bubuli" into global instances of anti-Romanian feeling, therefore embodiments of evil. The evolution can also be the result of the author exhausting the myriad of sensational "findings" regarding the 1989 Romanian Revolution, which sit at the core of the first several novels, and attempting to cover new and unexplored contents for the enactment of dramatic events. The typical pattern followed by his novels implies a first sequence, which falls into the convention of an adventure-style narrative and casts the spy Petre Varain as the hero, and a second and final sequence, which raises claims on being "nonfictional" and in which Corut himself acts as the hero, posing as an investigator of recent history (from the Romanian Revolution to the rise of the Islamic State). 84 volumes into the series, in Stăpânii din umbră [The Masters in the Shadows] (2008), Petre Varain loses his wife and child, who had been assassinated by "Zionists", but remarries and has a child with an extra-terrestrial female assigned to the alien mission that keeps Earth under observation, under the command of Zamolxe (to whom the members of the Octagon address as "Commander"), a mission whose outpost is hidden deep in the Carpathian Mountains (implying that Romania enjoys preferential treatment "from above"). Varain, having suffered a series of mutations under the influence of alien technology, has himself become half-alien.

The Octagon ranks among the top global secret agencies (having access to the aforementioned alien technology as well, which allows it to earn billions of dollars). However, notwithstanding its close ties with alien forces, Romania remains "at the bottom of the heap" (a contradiction for which Corut himself cannot find an explanation other than the stupidity of common people). Throughout the series, the sociological structure remains intact, and the members of the Octagon do not change - Commander Cremene ("Flint"), the drunken womaniser from Lipova, Bălaiul ("the blonde one"), and the technological genius Orozan (a low-budget version of James Bond's tech prodigy, Q). Racism (and even antisemitism) and ethnic clichés continue to be common occurrences. The narrative scheme is maintained throughout the entire series: Varain and the members of the Octagon go on a mission - searching after an artefact or an information, hunting down an occult organisation (the Masonic Lodge, the Islamic State, the Retrograde Occult, etc.) - which is invariably met with the utmost success. Only the timeline changes throughout the series; one of the most recent books, Viitorul creator [The 
Future Creator] from 2016, makes reference to Brexit and Donald Trump's presidential campaign.

Despite the popular success during the past decade, Corut has not managed to amass a following of likeminded authors trying to imitate his writing style and follow in his footsteps. One reason for this is certainly the weak representation of the thriller genre on the Romanian book market: it simply failed to emerge after 1989 , buried as it was under the massive output of translations. Among the few successful Romanian thriller authors worth mentioning is Adrian Onciu; his 2017 Cercul Kagan [The Kagan Circle], addressing contemporary themes such as terrorism and ecologism, construct a relatively efficient local pattern by mimicking Western models (nonetheless with limited local content, so that the novel gives the impression of actually being a translation).

Alongside Pavel Corut (whom he is by a large margin superior), Eugen Ovidiu Chirovici (b. 1964) is the most prominent name associated with commercial literature in postcommunist Romania. Chirovici became the subject of an article in The Guardian for having presumably sold an English-language thriller for a sevenfigure amount. Chirovici was not entirely unknown. Having made his debut in 1991 with two action-packed novels, Masacrul [The Massacre] and Comando pentru general [Commando for the General], Chirovici published throughout a wide range of genres: sensationalist nonfiction in Misterele istoriei. Religie, politică, bani [The Mysteries of History. Religion, Politics, Money] (2005), the comic novel in La broasca leșinată. Balada unui pierde-vară [At the Fainting Turtle. The Ballad of a Good-for-nothing] and Suflete la preț redus [Souls at a Discount] (both from 2007), the parodic crime novel in Cine a ucis-o pe Nora Jones [Who Killed Nora Jones?] (2011), the classic hardboiled novel the likes of Raymond Chandler in Voodoo (2010), conspiracy literature in Labyrinth.com (2009), the medieval novel along the lines of Umberto Eco's Name of the Rose in A doua moarte [The Second Death] (2006), horror à la Stephen King in Pulbere neagră [Black Powder] (2010), and Sanitarium. Locul în care nimic nu este ce pare a fi [Sanitarium. The Place Where Nothing is What it Seems] (2012). With the exception of La broasca leșinată. Balada unui pierde-vară and Suflete la preț redus, all of the books cultivate the illusion of being translations from Western authors: the settings and the characters are international and lack any Romanian background, and the quality of the writing is perfectly decent even in a global context, without displaying the common shortcomings typical of the few Romanian authors attempting to write commercial literature. His books are nearly perfect copies and point towards two somehow contradictory things: 1 . The attempt of the Romanian literary field to counteract the overwhelming threat posed by translations from the Anglo-Saxon cultural space by replicating their style (Chirovici delivers high-quality copies displaying the "naturally identical undertones" to which some of the books' presentations allude); 2 . The unfortunate backwardness of the same literary field, whose corresponding market is so restrained that "commercial literature" cannot become economically viable. 
Another relevant title is Biblia pierdută [The Lost Bible] (2015), the debut novel signed by Igor Bergler (b. 1970). On first glance, it is merely one of hundreds of copies after Dan Brown's The Da Vinci Code (the book's cover art hints towards this as well): a deeply buried ancient secret, planetary conspiration, clues hidden within various artefacts, mysterious and highly efficient assassins, cultural tourism, a romantic interest developing between the characters, and so on. However, the book proves to be much more intelligently written and exciting than this first impression would lead us to believe: conspiracy novel à la Dan Brown, excellently documented and ambitious in its proportions, it succeeded in combining a local material (Vlad the Impaler/Dracula) and an international literary formula (the conspiracy thriller). Moreover - something the author seemingly borrowed from Umberto Eco -, Biblia pierdută is much more self-ironic and metafictional than Brown's novels, therefore containing its own formula, but also the secret to its deconstruction. The Wikipedia page dedicated to the novel mentions a print run of over 130.000 copies $^{13}$.

Two years later, Igor Bergler publishes a new novel, Testamentul lui Abraham [Abraham's Testament], yet another conspiracy thriller which, according to the genre's established tradition, contrives secret societies and stories built on the principle of "connect everything": from Alexander the Great to Pope Ratzinger and Donald Trump, not forgetting to add the Great Library of Alexandria, Eldorado, fascists, and the Holocaust. Unlike Biblia pierdută, Bergler has almost entirely renounced the Romanian component (both regarding theme, as well as spatial setting), maintaining but few references to the Romanian origins of his protagonist, Charles Baker. The novel features a generous amount of literary references, from Cervantes, Umberto Eco, or the Voynich manuscript (which is to be found in Cărtărescu's Solenoid as well), and even to Borges (Death and the Compass is integrated into the text without any significant change). The characters themselves bear names with a literary or cinematographic veneer - Petra Menard (from Pierre Menard, featured in Borges as well), Mabuse, or Caligari. Endless intellectual conversations or anecdotes about Antiquity's lost books are intertwined with overthe-top action scenes. Of course, erudite thrillers are not a rare sight in Western libraries. But such a mix of inter- and metatextual elements is unusual in commercial literature. Bergler's novel rather displays the pattern of a postmodern metafictional novel.

\section{BIBLIOGRAPHY}

BOLTANSKI, Luc, Énigmes et complots, Paris, Gallimard, 2012.

HARPER, Mihaela P., "'In Agatha Christies Footsteps': The Cursed Goblet and Contemporary Bulgarian Crime Fiction", in Louise Nilsson, David Damrosch, Theo D'Haen (eds.), Crime Fiction as World Literature, New York, Bloomsbury Academic, 2017, pp. 171-186.

${ }^{13}$ Last accessed February 2, 2019. 
IUGA, Gabriel, Comoara regilor daci [The Treasure Trove of Dacian Kings], București, Editura Tineretului, 1969.

MARTÍN RODRÍGUEZ, Maríano, "Cine dictează canonul? Spirit conservator și inovație în istoriografia literară românească din primul deceniu al secolului al XXI-lea. Cazul literaturii științifico-fantastice" ["Who Dictates the Canon? Conservative Spirit and Innovation in Romanian Literary Historiography during the First Decade of the $21^{\text {st }}$ Century. The Case of Science Fiction Literature"], Viața românească, 2012, 7-8, pp. 135-136.

MORETTI, Franco, "Conjectures on World Literature", in Distant Reading, London - New York, Verso, 2013, pp. 43-62.

POPESCU, Cristian Tudor, "Ceaușescu a luat în mormânt și SF-ul românesc" ["Ceaușescu Took the Romanian Science Fiction Along to the Grave"]. Interview by Viorel Ilișoi, Jurnalul SF, 1994, 61, p. 15.

POPESCU, Cristian Tudor, "Literatura zilei" ["Literature of Today"], România literară, 1999, 31, p. 10.

SPINRAD, Norman, "Postfață" ["Afterword"], in Antologia science-fiction Nemira '94 [The 1994 Nemira Science Fiction Anthology]. Selected by Romulus Bărbulescu and George Anania. With a foreword by N. Lee Wood, București, Nemira, 1994.

YAN, Wei, "Sherlock Holmes Came to China: Detective Fiction, Cultural Meditations, and Chinese Modernity", in Louise Nilsson, David Damrosch, Theo D'Haen (eds.), Crime Fiction as World Literature, New York, Bloomsbury Academic, 2017, pp. 245-256.

\section{POPULAR GENRES: SCIENCE FICTION AND FANTASY, DETECTIVE NOVEL, THRILLER}

\section{(Abstract)}

This article presents from a historical point of view, starting from the $19^{\text {th }}$ century to the present, the evolution of the main paraliterary genres in Romanian literature (science-fiction and fantasy literature, detective literature, thriller). The study is theoretically based on a double hypothesis. First, that the evolution of these genres follows the Fredric Jameson-Franco Moretti "law" according to which in peripheral cultures the novel is imported as a form of compromise between a Western form and local materials. Secondly, that the communist period (1948-1989) is the reference period for the development of the popular fiction in Romania.

Keywords: Romanian literature, science fiction, fantasy, detective fiction, thriller.

\section{GENURI POPULARE: ROMANUL ȘTIINȚIFICO-FANTASTIC ȘI FANTASY, ROMANUL POLIT,IST, THRILLER (Rezumat)}

Acest articol prezintă din punct de vedere istoric, din secolul al XIX-lea până în prezent, evoluția principalelor genuri paraliterare din România (literatura science-fiction și fantasy, literatura polițistă, literatura de tip thriller). Studiul se bazează din punct de vedere teoretic pe o dublă ipoteză. În primul rând, că evoluția acestor genuri urmează „legea” Fredric Jameson-Franco Moretti potrivit căreia în culturile periferice romanul este importat ca o formă de compromis între o formă occidentală şi un fond local. În al doilea rând, că perioada de referință pentru dezvoltarea ficțiunii populare în România este perioada comunistă (1948-1989).

Cuvinte-cheie: literatură română, science-fiction, fantasy, literatură polițistă, thriller. 